\title{
Occurrence of phthirapteran ectoparasite parasitizing on domestic dogs, Canis familiaris (Linne) in J aunpur district (U.P.)
}

\section{Raj M ani Rao, Sur esh Chandra and Suneel K umar Singh ${ }^{1^{*}}$}

Department of Zoology, Kutir Post Graduate College, Chakke, Jaunpur-222 146 (Uttar Pradesh), INDIA

${ }^{1}$ Department of Biotechnology, Modern Institute of Technology, Dhalwala, Rishikesh-249 201(Uttarakhand), INDIA

"Corresponding author. E-mail: drsuneelkumarsingh@gmail.com

Received: March 28, 2013; Revised received: M ay 10, 2013; Accepted: May 28, 2013

\begin{abstract}
Only two species of biting louse, Heterodoxus spiniger (Enderlein) (43.27\%) and Trichodectes canis (De Geer) $(13.47 \%)$ have been recorded from 245 dogs examined in twelve different localities in Jaunpur district during 2009 to 2011. Female dogs were found most prevalent in comparison to the male in both the cases. Different parameters like host sex, hair colour, hygienic condition, health and age group have been taken into the consideration during the survey. Older age groups, unhealthy and unhygienic condition of dogs were found more prone for the lice. In case of relative intensity of lice $38 \%$ were found moderately infested with $\mathrm{H}$. spiniger while $23 \%$ and $16 \%$ were very light and light infested. Only $12 \%$ could be recorded heavy infested dog while $8 \%$ remained very heavy infested. Similar trends were recorded for T. canis where moderate infestation followed by very light, light, heavy and very heavy infestation respectively. Besides these two lice, some other ectoparasites (ticks, mites and fleas) $(5.31 \%)$ were also recorded casually but not used the data for prevalence.
\end{abstract}

Keywords: Phthiraptera, Dog lice, Occurrence, Heterodoxus spiniger; Trichodectes canis

\section{INTRODUCTION}

Phthiraptera is a group of economically important insects infesting birds and mammals. They spent their entire life span on the body of their host. They do not only affect the vitality and productivity of their hosts but are also responsible for reservoir and transmitting infectious agents among them. Askew (1971) and Marshall (1981) have excellently reviewed the work done on Phthiraptera while discussing about ecology of ectoparasitic insects. The phthirapterans occurring on dogs have not been studied intensely in different areas of world. Some workers casually mentioned the prevalence of dog lice. Bedford (1932) and Ewing (1936) did some taxonomical contribution on trichodectidae family. Crystal (1949) made a futile attempt to provide description relating to life history stages of Trichodectes canis, a dog louse. Amin and Madbouley (1973), while reporting the distribution and seasonal dynamics of a dog tick and a dog fly, made certain observations related to $H$. spiniger. He has simply recorded the incidence of infestation by $\mathrm{H}$. spiniger on dogs on Nile Valley and Delta of Egypt. Bouvier (1945) and Agarwal et al. (1982) have studied the feeding habits of T. canis and H . spiniger, respectively. Goel et al. (1990) have noted the incidence rate of $H$. spiniger and T. canis in Dehradun. A number of workers have studied the prevalence rate of ectoparasites infesting dogs but generally on fleas, ticks and mites. They casually reported the incidence rate, seasonal and distribution of dog lice along with other ectoparasites (Hewitt et al., 1971; Iwuala and Okpala, 1978; Gonzalez etal., 2004 , 2007; Badr et al ., 2005; Durden et al., 2005; Nithikathkul et al., 2005; Beck et al., 2006; Aldemir, 2007; Nuchjangreed and Somprasong, 2007; Agbolado et al., 2008; Chee et al., 2008; Gracia et al., 2008; Changbunjong et al., 2009; Xhaxhiu et al., 2009; Bahrami and Delpisheh, 2010; Beaucouru, 2001; Bermudez and Miranda, 2011; Kumsa and Mekonnen, 2011 and Jamshidi et al., 2012). Except these, the literature relating to phthirapteran ectoparasites of dog is entirely lacking particularly in this area. Keeping in view, the veterinary importance of these creatures and also the lacunae in the field an attempt was being made to study on the prevalence of phthirapteran ectoparasites occurring on dogs of some selected areas of district Jaunpur. This is the first hand report on the prevalence of $\operatorname{dog}$ lice in this area.

\section{MATERIALS AND METHODS}

All the results obtained during the survey of dogs are based on field observations. The live dogs (whether infested with lice or not) were subjected to critical examination by naked eye as well as with the help of hand lens which often proved fruitful in the presence of sufficient light. In order to record the phthirapteran species, the entire body of dogs was arbitrarily divided into 10 regions (i.e. head, neck, shoulders, back, belly, fore-arm, vulva, back-arm, tail and anus). The number of 
lice in every region was recorded by five point system used by Craufurd-Benson (1941) for cattle lice. This system provides an idea about the regional presence of lice. A wad of cotton soaked chloroform was used to rub in the body parts of the host so that the lice can narcotize and fall in the white plastic sheet already underneath the animal. Then a fine comb used to collect the entire lice from the body parts of the host. Chloroform evaporated very soon from the body of host and the lice were collected causing without harm to dogs. The collected lice were preserved in $90 \%$ alcohol and classified them into species-wise, sex-wise and stage-wise in the laboratory.

\section{RESULTS}

Two hundred and forty five (245) dogs from street as well as homes were examined in twelve different localities of Jaunpur district during January 2009 to December 2010, to record the incidence of different phthirapteran infestation. Only two dog lice species viz. Heterodoxus spiniger Enderlein and Trichodectes canis De Geer, could be noted along with some other ectoparasites (ticks, mites, fleas). Out of the 245 dogs examined in twelve different localities of Jaunpur district, 106 have been found infested with $\mathrm{H}$. spiniger ( $43.27 \%$ incidence of infestation). This species has been recorded from all the localities of Jaunpur district (Table 1). On the other hand, T. canis could be recorded from only $33(13.47 \%)$ of the examined dogs. This species were not recorded in three (Jalalpur, Line Bazaar Jaunpur and Mariahu) localities during the survey. However, few samples of ticks, mites and fleas were found present upon $13(5.31 \%)$ dogs. The collected species of ticks, mites and fleas could not be identified and so discarded from the prevalence. Although, their occurrence were indicated in table along with the phthirapteran species of dogs (Table 1).

Female dogs were found higher infested in comparison to male one as out of 159 female $45.28 \%$ were infested with $\mathrm{H}$. spiniger while out of 86 male $39.53 \%$ have lice infestation (Fig. 1). Similarly $15.09 \%$ female and $10.47 \%$ male dogs carried another phthirapteran species T. canis (Fig. 2). The dogs especially of poor hygienic condition were found more prevalent than normal and good one (Figs. 1,2). Similar results were obtained in health related parameters. Poorly maintained dogs and the street dogs have been found to be more susceptible to phthirapteran infestation in both the cases. T. canis occurs upon the street dogs having very poor skin condition. Hair colour of host was found insignificant as more or less similar prevalence rate of lice has been noted in black, white, brownish red, black \& white and spotted dogs (Figs. 1, 2). Dogs above 19 months years old were found infested with $45.28 \% \mathrm{H}$. spiniger followed by younger ones $(44.34 \%)$. More than $57 \%$ younger doges were infested with T. canis followed by older $(22.03 \%)$ (Figs. 1, 2). Intensity of infestation of lice was recorded by the distribution of lice on the body of host. The entire host body was arbitrarily divided into 10 regions (i.e. head, neck, shoulders, back, belly, fore-arm, vulva, back-arm, tail and anus) and lice species were counted region wise. The population of lice collected from each area was assessed by naked eye with the help of a hand lens and a sufficient light source. By experience, it became possible to assess the density of any population in one of five categories (1) very light infestation (VL) - one point; (2) light infestation (L) - two points; (3) moderate infestation (M) - three points; (4) heavy infestation $(\mathrm{H})$ - four points; (5) very heavy infestation $(\mathrm{VH})$ - five points.

Table 1. Locality-wise prevalence rate of dog lice (H. spiniger and T. canis) with some other ectoparasites (ticks, mites etc) from different localities of Jaunpur district.

\begin{tabular}{|c|c|c|c|c|}
\hline \multirow[t]{2}{*}{ L ocalities of } & \multirow{2}{*}{$\begin{array}{c}\text { Number of } \\
\text { dogs examined }\end{array}$} & \multicolumn{3}{|c|}{ Number and percentage of dogs infested with } \\
\hline & & H. spiniger & T. canis & $\begin{array}{c}\text { Other } \\
\text { ectoparasites }\end{array}$ \\
\hline Chakkey & 31 & $13(41.94 \%)$ & $07(22.58 \%)$ & $03(9.67 \%)$ \\
\hline Jalalpur & 17 & $08(47.06 \%)$ & - & $01(5.88 \%)$ \\
\hline Keraket & 23 & $10(43.48 \%)$ & $05(21.74 \%)$ & $01(4.35 \%)$ \\
\hline Line Bazar, Jaunpur & 12 & $05(41.67 \%)$ & - & - \\
\hline Matapur & 21 & $09(42.86 \%)$ & $02(9.52 \%)$ & $01(4.76 \%)$ \\
\hline Mariahu & 14 & $05(35.71 \%)$ & - & - \\
\hline Shakar Mandi & 19 & $09(47.37 \%)$ & $03(15.79 \%)$ & - \\
\hline Shahaganj & 27 & $11(40.74 \%)$ & $05(18.52 \%)$ & $02(7.41 \%)$ \\
\hline Thanagaddi & 15 & $06(40.0 \%)$ & $03(20.0 \%)$ & $01(6.67 \%)$ \\
\hline Trilochan Mahadeo & 19 & $10(52.63 \%)$ & $02(10.53 \%)$ & $01(5.26 \%)$ \\
\hline Vazidpur Farm & 18 & $08(44.44 \%)$ & $03(16.67 \%)$ & $01(5.56 \%)$ \\
\hline Zafarabad & 29 & $12(41.38 \%)$ & $03(10.34 \%)$ & $02(6.90 \%)$ \\
\hline TOTAL & 245 & $106(43.27 \%)$ & $33(13.47 \%)$ & $13(5.31 \%)$ \\
\hline
\end{tabular}


Host sex

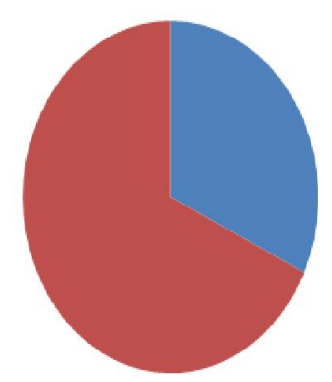

Hygienic condition

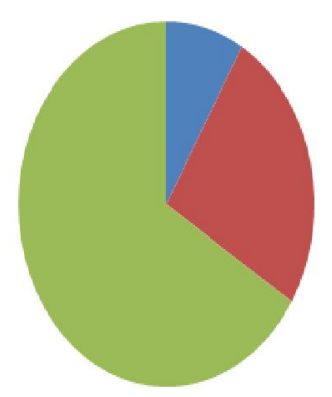

General health

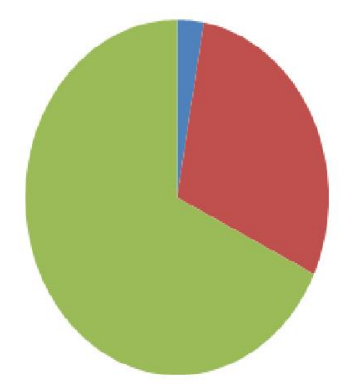

\section{— Male}

Female

Good

Normal

Poor

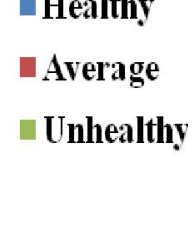

\section{Hair colour}

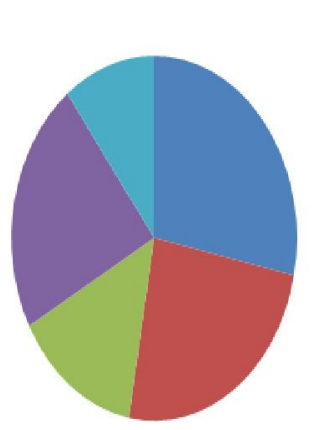

- Black

White

Brownish red

Black \& white

Spotted $\square 0$ to 6

$\square$ to 12

13 to 18

II- 19

\section{Relative intensity}

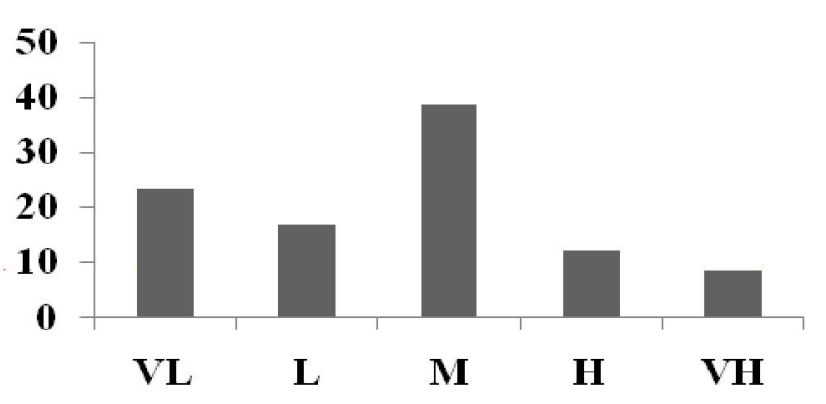

Fig. 1. Showing the impact of certain factors on incidence of dog louse, H. spiniger in J aunpur, during $2009-2011$.

Most of the dogs carried moderate lice (38\%) followed by very light (23\%), light (16\%), heavy (12\%) and very heavy $(8 \%)$ infestation concerning with $\mathrm{H}$. spiniger (Fig. 1). Similar results have been obtained from T. canis infestation where moderate infestation was noted 39\%, followed by very light (30\%). Light (18\%), heavy (9\%) and very heavy (3\%) (Fig. 2).

Date regarding the presence and number of eggs observed were not used as these could not be detached from a live dog due to glue with hair and skin of the host. Although, few samples of the lice eggs were collected to confirmation of the collected species. Injured areas of dogs are more prone for T. canis as it was collected mostly from wounds. Some T. canis were also recorded from head and neck region of the host body.

\section{DISCUSSION}

Present study is the first hand report on incidence of phthiratperan infestation upon the dogs in Jaunpur district (U.P.). Earlier, Amin and Madbouly (1973) have made an attempt to record the incidence of infestation by $\mathrm{H}$. spiniger in Nile Valley and Delta of Egypt. In Egypt, Amin and Madbouly (1973) has recorded only 5\% infestation by $\mathrm{H}$. spiniger whereas in Jaunpur district incidence rate of same was found significantly higher $(43.27 \%)$. Moreover, Amin and Madbouly (1973) did not record T. canis from Egypt. In Jaunpur district T. canis was recorded on $13.47 \%$ dogs. Goel et al. (1990) could record $19.51 \%$ $H$. spiniger and $4.39 \%$ T. canis from Dehradun. Gonzalez et al. (2004) has also reported T. canis along with fleas, mites and ticks. Parameters like host health, hair/skin colour, hygienic condition and age were included for determination impact on prevalence of dog lice. Hair colour of host seems to be insignificant as more or less similar result for prevalence were obtained during present study. Poor health and unhygienic condition were found 
Host sex

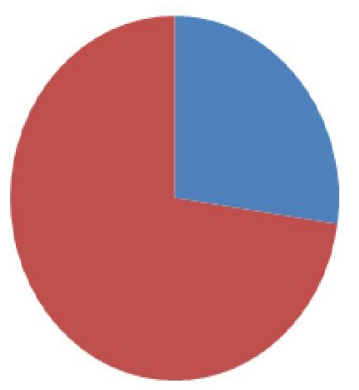

Hygienic condition

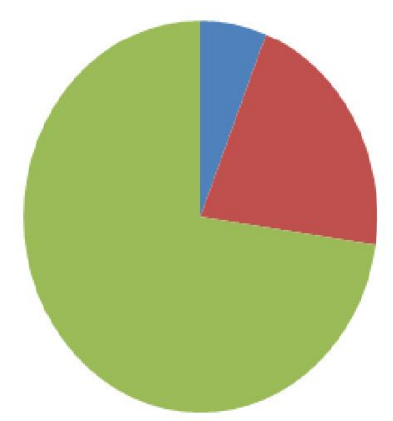

General health

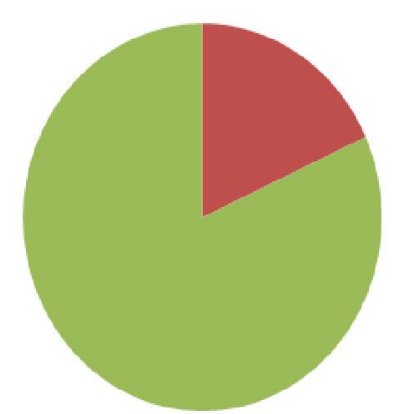

- Male

- Female

Good

- Normal

Poor

- Healthy

- Average

Unhealthy

\section{Hair colour}

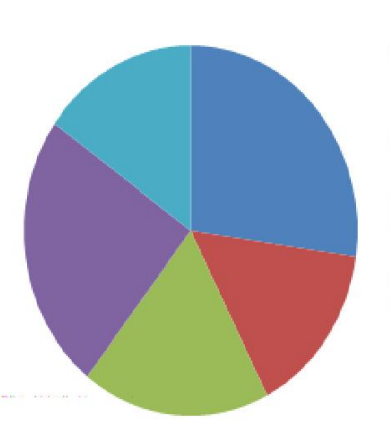

Age group

0 to 6

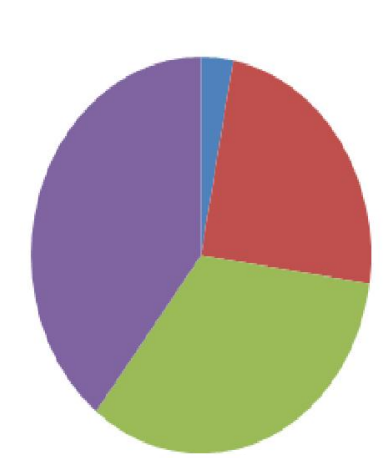

Relative intensity

Black

White

Brownish red

Black \& white

Spotted

- 7 to 12

13 to 18

- $>19$

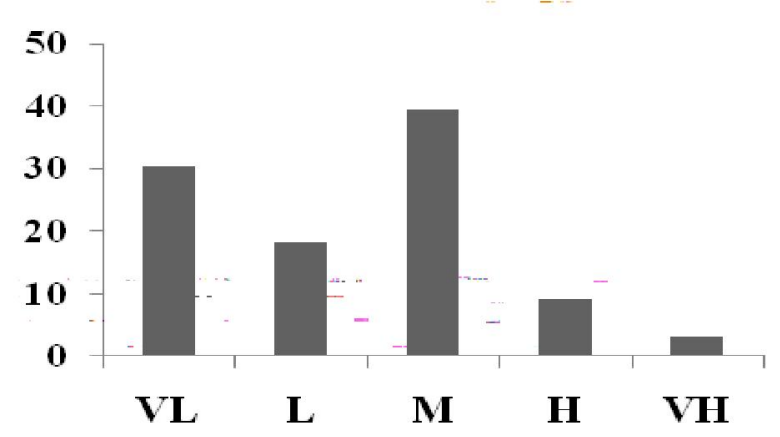

Fig. 2. Showing the impact of certain factors on incidence of dog louse, T. canis in J aunpur, during 2009 - 2011.

most prone for $\mathrm{H}$. spiniger and T. canis. Most of the workers paid their attention on prevalence of fleas, ticks and mites of dogs and cats and rarely pointed on the phthirapteran species (Hewitt et al., 1971; Iwuala and Okpala, 1978; Sehwartz et al., 1983; Mech et al., 1985; Wall and Shearer, 2001; Gonzalez et al., 2004; Durden et al., 2005; Nithikathkul et al., 2005; Beck et al., 2006; Aldemir, 2007; Nuchjangreed and Somprasong, 2007; Torres and Figueredo, 2007; Agbolado et al., 2008; Chee et al., 2008; Gracia et al., 2008; Shourijeh et al., 2008; Changbunjong et al., 2009; Xhaxhiu et al., 2009; Bahrami and Delpisheh, 2010; Kumsa and Mekonnen, 2011; Norhidayu et al., 2012 and Wells et al., 2012). Recently, Jamshidi et al. (2012) noted the prevalence of T. canis and Linognathus setosus $(8.4 \%)$ in Tehran. In present studies ticks, mites and fleas was also reported but not included in the prevalence.

\section{ACKNOW LEDGEMENTS}

Authors are thankful to Director, Modern Institute of Technology, Dhalwala, Rishikesh and Principal, Kutir (P.G.) College, Chakke, Jaunpur (U.P.) for providing laboratory and to Dr. A.K. Saxena (Phthirapterilogist, U.P.) for valuable help in identification of mammalian lice species and preparation of manuscript.

\section{REFERENCES}

Agarwal, GP., Chandra, S. and Saxena, A.K. (1982). Feeding habits of dog ouse, H eterodoxus spiniger (End.) (Mallophaga: Amblycera). J ournal of Applied Entomology, 94(2): 134-137.

Agbolado, O.M., Soetan, E.O., Awesu, A.,Ojo, J.A., Somoye, O.J. and Raufu, S.T. (2008). Ectoparasites of domestic dogs in some Ijebu Communities, Southwest Nigeria. World Applied Science J ournal, 3(6): 916-920.

Aldemir, O.S. (2007). Epidemiological study of ectoparasites in dogs from Erzurum region in Turkey. Revue de M edecine 
Veterinaire, 158(3): 148-151.

Amin, O.M. and Madbouly, M.H. (1973). Distribution and seasonal dynamics of a tick, a louse fly, and a louse infesting dogs in the Nile valley and delta of E gypt. J . M ed. Ent., 10: 295-298.

Askew, R.R. (1971). Parasitic insects. London (Heineman Educational Books)

Badr, V. Stefan, P. and Preisler, J. (2005). Trichodectes canis (De Geer, 1778) (Phthiraptera, Ischnocera), a new ectoparasite of the raccoon dog (Nycter eutes procyonoides) in the Czech Republic. European J ournal of Wildlife Research, 51(2): 133-135.

Bahrami, A.M. and Delpisheh, A. (2010). Common ectoparasites species of domestic dogs in western Iran. World Applied Science J ournal, 8(10): 1277-1281.

Beaucouru, J.C., Jouan, R. and Menier, K. (2001). Ectoparasite insects of the dog in Laos. Revue de M edecine Veterinaire, 152: 77-82.

Beck, W., Boch, K., Mackensen, H., Wiegand, B. and Pfister, K. (2006). Qualitative and quantitative observations on the flea population dynamics of $\operatorname{dog} s$ and cats in several areas of Germany. Veterinary Parasitology J ournal, 137(1-2): 130-136.

Bedford, G.A.H. (1932). Trichodectidae (Mallophaga) parasitic on Procaviidae. Proceedings of the Zoological Society of London, (3): 709-730.

Bermudez, S.C. and Miranda, R.C. (2011). Distribution of ectoparasites of canis Iupus familiaris L. (Carnivora: Canidae) from Panama. Rev. M VZ Cordoba, 16(1): 22742282.

Bouvier, G. (1945). De'l haemophagie de quelques Mallophages des animaux domestques. Schqeiz. Arch. Tierheilk., 87: 429-434

Changbunjong, T., Buddhirongawatr, R., Suwanpakdee, S., Siengsanan, J., Yongyuttawichai, P., Cheewajorn, K., Jangjaras, J., Sangloung, C. and Ratanakorn, P. (2009). A survey of ectoparasitic arthropods on domestic animals in Tak pronince, Thailand. Southwest Asian J ournal of Tropical M edecine and P ublic Health, 40(3): 435-442.

Chee, J.H., Kwon, J.K., Cho, H.S., Cho, K.O., Lee, Y.J. and El-Aty, A.M.A. (2008). A survey of ectoparasites infestation in stray dogs of Gwang-ju-City, Republic of Korea. Korean J ournal of Parasitology, 46(1): 23-27.

Craufurd-Benson, H.J. (1941). The cattle lice of Great Britain. Part I. Biology with special reference to Haematopinus eurysturnus. Parasitology, $33: 331-358$.

Crystal, M.M. (1949). A descriptive of the life history stages of the dog biting louse, Trichodectes canis (DeGeer) (Mallophaga: Trichodectidae). Bull. Brooklyn Entomol. Soc. (Brooklyn), 44: 89-97.

Durden, L.A., Judy, T.N., Martin, J.E. and Spedding, L.S. (2005). Fleas parasitizing domestic dogs in Georgia, U.S.A.: Species composition and seasonal abundance. Veterinary Parasitology., 130(1-2): 157-162.

Ewing, H. (1936). The taxonomy of the mallophagan family Trichodectidae, with special reference to the new world fauna. J ournal of P arasitology., 22(3): 233-246.

Goel, N.K., Rawat, B.S. and Saxena, A.K. (1990). Incidence of phthirapteran infestation upon the dogs of Dehradun. J. Zool. Res., 3(1): 19-23.
Gonzalez, A.; Castro, D.D.C. and Gonzalez, S. (2004). Ectoparasitic species from Canis familiaris (Linne) in Buenos Aires province, Argentina. Veterinary Parasitology., 120(1-2): 123-129.

Gonzalez-Acuna, D., Briceno, C., Cicchino, A., Funk, S. and Jimenez, J. (2007). First records of Trichodectes canis (Insecta : Phthiraptera : Trichodectidae) from Darwin's fox, Pseudolopex fulvipes (Mammalia: Carnivora: Canidae). European Journal of Wildlife Research., 53(1): 76-79.

Gracia, M.J., Calvete, C., Estruda, R., Castillo, J.A., Peribanez, M.A. and Lucientes, J. (2008). Fleas parasitizing domestic dogs in Spain. Veterinary Parasitology., 151(2-4): 312-319.

Hewitt, M., Walton, G.S. and Waterhouse, M. (1971). Pet animal infestation and human skin lesions. Nr. J . Dermatol., 85(3): 215-225.

Iwuala, M.O.E. and Okpala, I. (1978). Studies on the ectoparasitic fauna of Nigerian livestock II: Seasonal infestations rates. Inter-African Bureau for Animal Resources, (26(4): 351-359.

Jamshidi, S., Maazi, N., Ranjbar-Bahadori, S., Rezaei, M., Morakabsaz, P. and Hosseininejad, M. (2012). A survey of ectoparasite infestation in dogs in Tehran, Iran. Revista Brasileira de Parasitology Veterinaria, 21(3): 326-329.

Kumsa, B.E. and Mekonnen, S. (2011). Ixodid ticks, fleas and lice infesting dogs and cats in Hawassa, southern Ethiopia. Onderstepoort J ournal of Veteinary Research, 78(1): 326-330.

Marshall, A.G. (1981). The ecology of ectoparasitic insects. Academic Press, London. 459.

Mech, L., Thiel, R., Fritts, S. and Berg, W. (1985). Presence and effects of the dog louse Trichodectes canis (Mallophaga, Trichodectidae) on Wolves and Coyotes from Mennesota and Wisconsis. American Midland Naturalist, 114(2): 404-405.

Nithikathkul, C., Polseela, R., Iamsa Ard, J., Wongsawad, C. and Jittapalapong, S.A. (2005). A study of ectoparasites of Canis lupus familiaris in Mueang district, Khon Kaen, Thailand. Southwest Asian J ournal of Tropical Medecine and Public Health, 36(S-4): 149-151.

Norhidayu, S., Mohd Zain, S.N., Jeffery, J. and Lewis, J.W. (2012). The dog louse Heterodoxus spiniger from stray cats in Penang, Malaysia. Tropical Biomedicine, 29(2): 301-303.

Nuchjangreed, C. and Somprasong, W. (2007). Ectoparasite species found on domestic dogs from Pattaya district, Chon Buri province, Thailand. SouthwestA sian J ournal of Tropical Medecine and Public Health, 38(S-1): 203-207.

Sehwartz, C., Stephenson, R. and Wilson, N. (1983). Trichodectes canis on the Gray Wolf and Coyote on Kenai Peninsula, Alaska. J ournal of Wildl ife D isease, 19(4) 372-373.

Shourijeh, S.J., Ghasrodashti, A.R., Tamadon, A., Moghaddar, N. and Behzadi, M.A. (2008). Seasonal frequency of ectoparasites infestation in dogs from Zhiraz, Southern Iran. Turkish J ournal of Veterinary and Animal Science, 32(4): 309-313.

Torres, F.D. and Figueredo, L.A. (2007). H eter odoxus spiniger (Enderlein, 1909) on domestic dogs (Canis familiaris, L. 1758) from the city of Recife, Pernambuco State, Brazil. Brazilian J ournal of Veterinary and Animal Science, 44(2): 77-80. 
Wall, R. and Shearer, D. (2001). Veterinary ectoparasites: Biology, pathology and control, 2nd ed. Blackwell Sciences Ltd, Oxford London Press.

Wells, K., Beaucournu, J.C., Durden, L.A., Petney, T.N., Lokim, M.B. and O'Hara, R.B. (2012). Ectoparasitic dogs in suburban and rural areas in Borneo. Parasitol. Res., 111: 909-919.

Xhaxhiu, D., Kusi, I., Rapti, D., Visser, M., Knaus, M. and Lindner, T. (2009). Ectoparasites of dogs and cats in Albania. Parasitological Research, 105(6): 1577-1587. 